Article

\title{
Crosstalk between BMP and Notch Induces Sox2 in Cerebral Endothelial Cells
}

\author{
Xiuju Wu ${ }^{1, \dagger}{ }^{+}$Jiayi Yao ${ }^{1, \dagger}{ }^{+}$Lumin Wang ${ }^{1,2}$, Daoqin Zhang ${ }^{1}$, Li Zhang ${ }^{1}$, Eric X. Reynolds ${ }^{1}$, \\ Tongtong Yu ${ }^{1,3}$, Kristina I. Boström ${ }^{1,4, *}$ and Yucheng Yao ${ }^{1, *}$ \\ 1 Division of Cardiology, David Geffen School of Medicine at UCLA, Los Angeles, CA 90095-1679, USA; \\ XiujuWu@mednet.ucla.edu (X.W.); jyao@mednet.ucla.edu (J.Y.); wanglumin1@126.com (L.W.); \\ daoqinzhang@mednet.ucla.edu (D.Z.); LiZ@mednet.ucla.edu (L.Z.); ericx02@icloud.com (E.X.R.); \\ tongtongyu@mednet.ucla.edu (T.Y.) \\ 2 Department of cell Biology and Genetics, School of Basic Medical Sciences, Xi'an Jiaotong University Health \\ Science Center, Xi'an, 710061, China \\ 3 Department of Cardiology, Shengjing Hospital of China Medical University, Shenyang 110004, China \\ 4 The Molecular Biology Institute at UCLA, Los Angeles, CA 90095-1570, USA \\ * Correspondences: kbostrom@mednet.ucla.edu (K.I.B.); yyao@mednet.ucla.edu (Y.Y.); Tel.: 310-794-4417 \\ (K.I.B.); +310-825-3239 (Y.Y.) \\ + These authors contributed equally to this work.
}

Received: 23 April 2019; Accepted: 5 June 2019; Published: 6 June 2019

\begin{abstract}
Bone morphogenetic protein (BMP) and Notch signaling are critical for endothelial cell (EC) differentiation in vascular development. Recent studies have shown that excess BMP activity induces Notch signaling in cerebral ECs resulting in arteriovenous malformation (AVMs). However, it is unclear how the crosstalk between BMP and Notch signaling affects cerebral EC differentiation at the gene regulatory level. Here, we report that BMP6 activates the activin receptor-like kinase (ALK) 3 , a BMP type 1 receptor, to induce Notch1 receptor and Jagged1 and Jagged2 ligands. We show that increased expression of the Notch components alters the transcriptional regulatory complex in the SRY-Box 2 (Sox2) promoter region so as to induce its expression in cerebral ECs. Together, our results identify Sox 2 as a direct target of BMP and Notch signaling and provide information on how altered BMP and Notch signaling affects the endothelial transcriptional landscape.
\end{abstract}

Keywords: Sox2; bone morphogenetic protein; Notch; endothelial cells

\section{Introduction}

The bone morphogenetic protein (BMP) and Notch signaling pathways are essential for vascular development and homeostasis, and disruption of these pathways is known to cause vascular disease. Mutations of the activin receptor-like kinase (ALK) 1, a BMP type I receptor, are linked to hereditary hemorrhagic telangiectasia 2 (HHT2), which is characterized by the presence of arteriovenous malformation (AVMs) in multiple organs including the brain [1,2]. Excess BMP4 and BMP6 activities are known to contribute to cerebral vascular malformation [3,4], and loss of the BMP inhibitor matrix Gla protein (MGP) causes AVMs in brain, lungs, and kidneys, similar to HHT2 [4,5]. Notch components are considered to be critical mediators of endothelial cell fate decisions and vascular lumen formation [6,7], and both loss-of-function and gain-of-function Notch mutations result in arteriovenous shunting [8,9]. Constitutively active Notch4, in particular, causes brain AVMs $[10,11]$. Recent studies from our lab showed that lack of BMP inhibition induces the expression of Notch components in endothelial cells (ECs), which results in cerebral AVMs [4,12]. However, it is poorly understood how the interactions between BMP and Notch signaling alter transcriptional regulation in cerebral ECs, contributing to vascular disease in the brain. 
Sox2 belongs to the Sox family of transcription factors, characterized by a DNA-binding high mobility group (HMG) box domain [13,14]. Sox2 is a well-known cell fate regulator and functions as an important transcription factor for tissue development [15] and cell reprogramming [14]. Sox2 is also involved in cell-cell transitions, such as epithelial-mesenchymal transitions [16,17] and endothelial-mesenchymal transitions [18]. Here, we report that interactions between BMP and Notch signaling induce Sox2 expression in cerebral ECs. We show that BMP6 activates the BMP type 1 receptor ALK3, increasing the expression of specific Notch ligands and of a Notch receptor, that in turn activate the expression of Sox 2 in cerebral ECs.

\section{Materials and Methods}

\subsection{Animals}

$\mathrm{Mgp}^{+/-}$(B6.129S7-Mgptm1Kry/KbosJ), Jagged1 ${ }^{+/-}$(B6.129S1-Jag1tm1Grid/J), Jagged2+/- (B6.129S1Jag2tm1Grid/J), Cdh5 ${ }^{\text {Cre }}$ (B6.Cg-Tg(Cdh5-cre)7Mlia/J), and Notch1 Flox/Flox (Notch1tm2Rko/GridJ) mice on a C57BL/6J background were obtained from the Jackson Laboratory. The genotypes were confirmed by PCR [19], and the experiments were performed with generations F4-F6. Littermates were used as wild-type controls. All mice were fed a standard chow diet (Diet 8604, HarlanTeklad Laboratory). The studies were reviewed and approved by the Institutional Review Board and conducted in accordance with the animal care guidelines set by the University of California, Los Angeles. The investigation conformed to the National Research Council, Guide for the Care and Use of Laboratory Animals, Eighth Edition (Washington, DC: The National Academies Press, 2011).

\subsection{Tissue Culture}

Human brain microvascular cells (HBMECs) were obtained from ScienCell Research Laboratories and cultured as per the manufacturer's protocol. For treatment, Jagged1 and 2 (R\&D Systems) were added as indicated in the Results section. Transient transfections of HBMECs with siRNA (Silencer®predesigned siRNA, Applied Biosystem, Foster City, CA, USA) were optimized and performed as previously described [5]. When compared to unrelated control siRNA and scrambled siRNA, the selected siRNAs resulted in a 90-95\% decrease in mRNA and protein levels, as determined by real-time PCR and immunoblotting, respectively. Silencerßpredesigned siRNAs were obtained for ALK2, 3, 4, 6, and 7 and Notch1, 2, 3, and 4.

\subsection{Isolation of Cerebral ECS}

Cerebral EC were isolated as previous described [20]. Briefly, mouse cerebra were collected after systemic perfusion with phosphate-buffered saline (PBS). The cerebra were transferred to a Petri dish, cut into small pieces, and treated with $0.5 \%$ collagenase. The mixture was incubated at $37^{\circ} \mathrm{C}$ with slow rotation for 30 minutes. After the incubation, a Pasteur pipette was applied with gentle pressure to disaggregate the tissues. The cell suspension was filtered through a $100 \mu \mathrm{m}$ mesh into a new tube, and centrifuged at $300 \times g$ for 5 minutes at $4{ }^{\circ} \mathrm{C}$. The cell pellet was re-suspended in PBS with $2 \%$ BSA for incubation with primary CD31 and CD45 antibodies to label the cells for flow-cytometric sorting. $\mathrm{CD} 31^{+} \mathrm{CD} 45^{-}$cells were collected for EC experiments, and the remaining cells were used as controls.

\subsection{RNA Analysis}

Real-time PCR analysis was performed as previously described [21]. Glyceraldehyde 3-phosphate dehydrogenase (GAPDH) was used as a control gene [21]. Primers and probes for mouse or human Jagged1, Jagged2, Notch 1-4, Dll 1, 3, and 4, and Sox2 were obtained from Applied Biosystems as part of TaqMan Gene Expression Assays. 


\subsection{Immunoblotting}

Immunoblotting and immunoprecipitation were performed as previously described [22]. Equal amounts of tissue lysates were used for immunoblotting. Blots were incubated with specific antibodies to Sox2 (Abcam, Cambridge, MA, USA, ab97959). Beta-Actin (1:5000 dilution; Sigma-Aldrich, St. Louis, $\mathrm{MO}, \mathrm{USA})$ was used as a loading control.

\subsection{Chromatin Immunoprecipitation (ChIP) Assay}

ChIP assays were performed as previously described [23]. Briefly, glycine was added to the cells to a concentration of $0.125 \mathrm{M}$ to quench the crosslinking. The cells were then rinsed with ice-cold PBS, re-suspended, lysed in lysis buffer, and sonicated to shear the crosslinked DNA to fragments ranging from 200 to $500 \mathrm{bp}$, as previously described [24]. The lysates ere incubated with specific antibodies or normal IgG at $4{ }^{\circ} \mathrm{C}$ overnight. After adding $40 \mu \mathrm{L}$ of protein $\mathrm{G}$ magnetic beads, the lysates were further incubated for 2-3 hours. The beads were washed repeatedly, and the DNA was eluted from the beads by incubating in $10 \mathrm{mM}$ Tris- $\mathrm{Cl}, \mathrm{pH} 8.5$, for 15 minutes at $65^{\circ} \mathrm{C}$. Both the immunoprecipitated and the input DNA samples were incubated overnight at $65^{\circ} \mathrm{C}$ for reversal of the crosslinking. The DNA samples were then purified by sequential phenol/chloroform/isoamyl alcohol (Sigma) extraction. The final DNA products were ethanol-precipitated, and the pellets were air-dried and dissolved in $10 \mathrm{mM}$ Tris- $\mathrm{HCl}$. The primers were used for the ChIP assay as previously described [25]. Anti-RBPJ (Abcam, ab25949), anti-NICD1 (Abcam, ab83232), and anti-MAM (Abcam, ab17019) antibodies were used for the ChIP assays.

\subsection{ChIP-seq}

ChIP-seq of DNA from $\mathrm{Mgp}^{-/}$and $\mathrm{Mgp}^{+/+}$cerebral ECs were performed using specific anti-H3K4me3 (Abcam, rabbit ab8580) and anti-H3K27me3 (Abcam, mouse ab6002) antibodies in order to enrich the genomic DNA. ChIP DNA was sequenced by the Technology Center for Genomics and Bioinformatics at UCLA. Reads from each sample were mapped to the human genome by using Bowtie2. The HOMER tool was used to detect a significant enrichment of peaks with $5 \%$ false discovery rate and more than four-fold over-input. Motif occurrences in peaks were identified by The HOMER Motif Discovery function. Peak annotation was performed to associate peaks with nearby genes to calculate tag densities.

\subsection{Statistical Analysis}

Data were analyzed for statistical significance by ANOVA with post-hoc Tukey's analysis. The analyses were performed using GraphPad Instat $囚$, version 3.0 (GraphPad Software, San Diego, CA, USA). Data represent mean \pm SD; $p$-values less than 0.05 were considered significant, and experiments were repeated a minimum of three times.

\section{Results}

\subsection{Excess BMP Activity Induces Notch in Cerebral ECs}

MGP is an inhibitor of BMP 2, 4, 6, and 7, and the MGP-deficient $\left(\mathrm{Mgp}^{-/}\right)$mouse is a well-documented model of cerebral AVMs. To determine which Notch ligands and receptors are induced by excessive BMP signaling, we isolated $\mathrm{Mgp}^{-/-}$cerebral ECs (Figure 1a) and examined the components of the Notch signaling pathway, including Notch receptors 1, 2, 3, and 4, Notch ligands Jagged 1 and 2 and Delta-like (Dll) 1,3, and 4. The results showed that the expression of Notch1 and Jagged1 and 2 was significantly increased in $\mathrm{Mgp}^{-/}$cerebral ECs, as determined by real-time PCR (Figure 1b), suggesting that these Notch components were BMP downstream targets in cerebral ECs. 


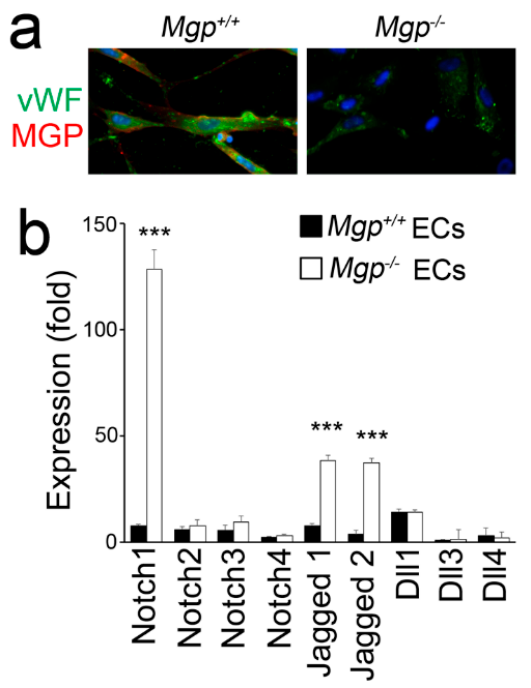

Figure 1. Increased Notch signaling in $\mathrm{Mgp}^{-/-}$cerebral endothelial cells (ECs). (a) Immunostaining of cerebral ECs isolated from wild-type $\left(\mathrm{Mgp}^{+/+}\right)$and $\mathrm{Mgp}^{-/-}$mice. The cells were incubated for 24 hours to let them attach to the slides before staining; vWF, von Willebrand factor. (b) Expression of Notch receptors 1, 2, 3, and 4, and Notch ligands Jagged1 and 2 and Delta-like (Dll)1, 3, and 4 in cerebral ECs isolated from wild-type $\left(\mathrm{Mgp}^{+/+}\right)$and $\mathrm{Mgp}^{-/-}$mice $(\mathrm{n}=8)$, as determined by real-time PCR. ${ }^{* * *} p<0.001$.

\subsection{BMP6 Activates ALK3 to Induce Notch in Brain ECs}

To identify which BMP ligand and receptor were responsible for the induction of the Notch components, we treated HBMECs with different doses of BMP ligands $(0-300 \mathrm{ng} / \mathrm{mL})$, including BMP2, 4, 6, 7, 9, and 10, according to previous studies [5,19,26-30]. After $48 \mathrm{~h}$ of treatment, we examined the expression of Notch1 and Jagged1 and 2 and found that BMP6 strongly induced these proteins (Figure 2a). In addition, BMP9 mildly induced the same Notch components (Figure 2a). To further differentiate the responses, we treated HBMECs with BMP6 $(100 \mathrm{ng} / \mathrm{mL})$ and BMP9 $(10 \mathrm{ng} / \mathrm{mL})$. The results showed that BMP9 induced all the ligands and receptors of the Notch pathways, similar to what observed in our previous study [4], whereas BMP6 only induced the expression of Notch1 and Jagged 1 and 2 (Figure 2a,b). Indeed, the BMP6 induction patterns of Notch1 and Jagged1 and 2 in HBMECs were similar to the induction patterns in the cerebral endothelium of $\mathrm{Mgp}^{-/-}$mice.

Furthermore, we treated HBMECs with BMP6 and examined the phosphorylation (p) of SMAD $1 / 5 / 8$ after 30 and $60 \mathrm{~min}$ of treatment. The results showed that pSMAD1/5/8 was significantly increased at $30 \mathrm{~min}$ and even more at $60 \mathrm{~min}$ (Figure 2c), suggesting that the early response to BMP6 in HBMECs was mediated by pSMAD1/5/8. We then examined the Notch1 intracellular domain (NICD1) and found that NICD1 was significantly increased after 5 and $10 \mathrm{~h}$ of BMP6 treatment in HBMECs (Figure 2d). The results suggested that BMP6 induced the Notch components through pSMAD1/5/8.

To assess BMP expression in Mgp $p^{-/}$brains, we examined the levels of BMPs using real-time PCR and compared them to those of wild-type brain. The results showed no significant difference between wild-type and $\mathrm{Mgp}^{-/-}$brains (Figure 2e). The results were consistent with those of our previous studies $[5,27,29]$, which showed that the lack of MGP increased BMP activity but not necessarily its expression. Together, the results suggested that excess activity of BMP6 in cerebral ECs caused the induction of Notch1 and Jagged1 and 2.

To determine which receptor was activated by BMP6 to induce Notch, we individually depleted ALK-2, 3, 4, 6, and 7 in BMP6-treated HBMECs using specific siRNAs. The selected siRNAs decreased the targeted mRNA by $90 \%-95 \%$ compared to scrambled siRNA, as determined by real-time PCR (Figure 3a). The results showed that the depletion of ALK3 abolished Notch induction in BMP6-treated HBMECs (Figure 3b-d), suggesting that BMP6 activated ALK3 to induce Notch1 and Jagged 1 and 2 through ALK3 signaling. 
a $₫ \mathrm{BMP2} \backsim \mathrm{BMP4} \backsim \mathrm{BMP6} \backsim \mathrm{BMP7} \backsim \mathrm{BMP9} \backsim \mathrm{BMP} 10$
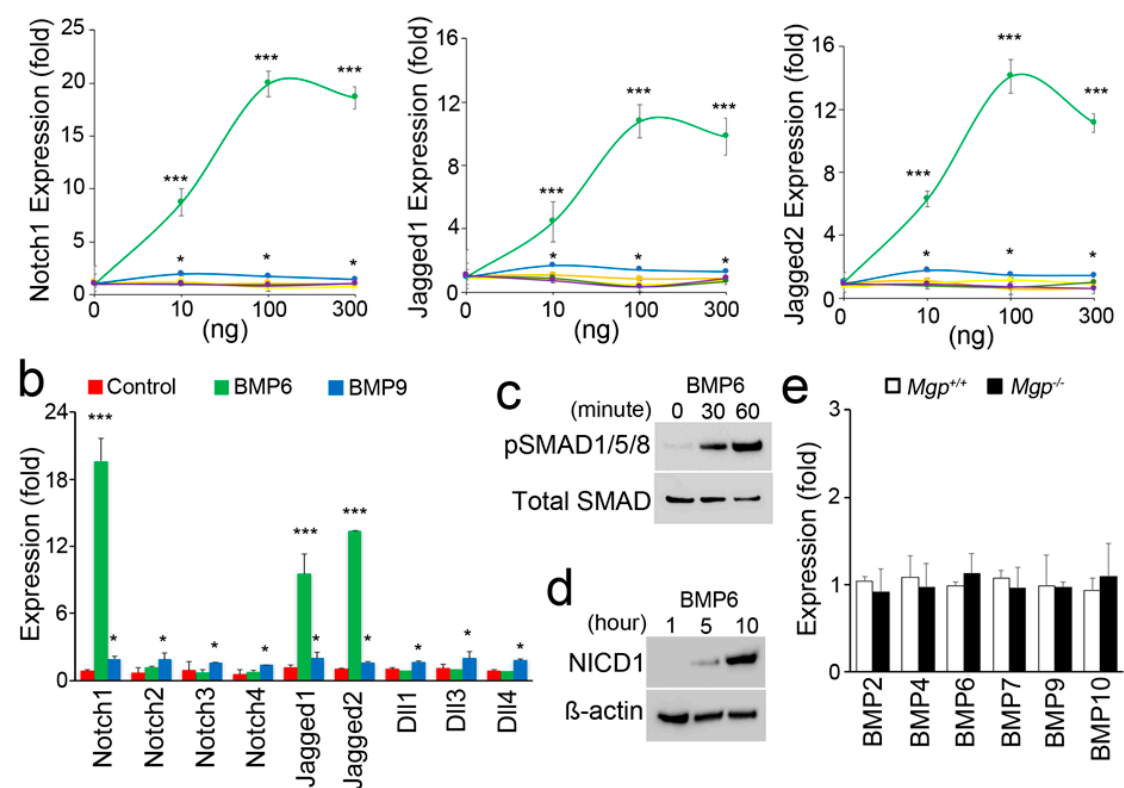

Figure 2. Bone morphogenetic protein 6 (BMP6) induces Notch1 and Jagged1 and 2 in cerebral ECs. (a) Expression of Notch1 and Jagged1 and 2 in human brain microvascular cells (HBMECs) treated with different doses of BMP2, 4, 6, 7, 9, or 10. (b) Expression of components of the Notch pathway in HBMECs treated with BMP6 $(100 \mathrm{ng} / \mathrm{mL})$ and BMP9 $(10 \mathrm{ng} / \mathrm{mL})$. (c) Immunoblotting of pSMAD1/5/8 in HBMEC at 0, 30, and 60 min of treatment with BMP6. (d) Immunoblotting of Notch1 intracellular domain (NICD1) in HBMECs at 1, 5, and $10 \mathrm{~h}$ of treatment with BMP6. (e) Expression of BMPs in cerebra $(\mathrm{n}=5) .{ }^{*} p<0.05 ;{ }^{* * *} p<0.001$.
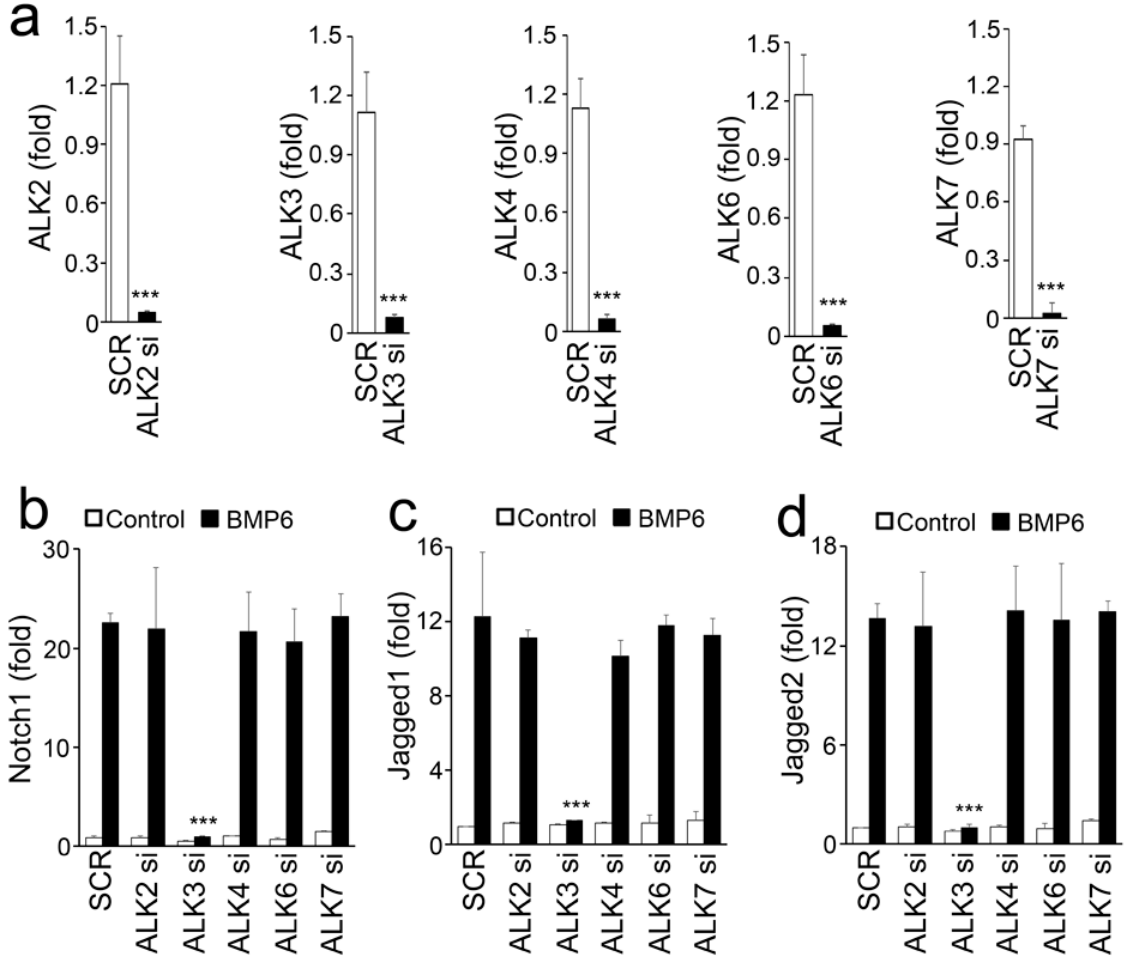

Figure 3. BMP6 induces Notch signaling through the activation of ALK3. (a) Expression of ALK2, 3, 4, 6, and 7 in HBMECs after transfection with individual siRNAs. (b-d) Expression of Notch1 (b), Jagged1 (c) and 2 (d) in BMP6-treated HBMECs after transfection with specific siRNAs (si) to ALK2, ALK3, ALK4, ALK6, or ALK7. ${ }^{* * *} p<0.001$. 


\subsection{Elevated Notch Signaling Induces the Expression of Sox2}

Our previous studies showed that lack of BMP inhibition increased Sox2 in the aortic endothelium and altered endothelial cell fate to contribute to vascular calcification [18]. To determine if Notch signaling affected Sox2 expression in brain ECs, we treated HBMECs with Jagged1, Jagged2, or their combination. We found that Jagged 1 and 2 strongly induced Sox 2 expression, and the induction was even higher when they were added in combination (Figure 4a,b). NICD1 was used as a control to show the activation of the Notch1 pathway (Figure $4 \mathrm{~b}$ ). To identify which Notch receptor was activated by Jagged 1 and 2 to induce Sox 2 expression, we individually depleted Notch1, 2, 3, and 4 in HBMECs treated with Jagged 1 and 2 (Figure $4 \mathrm{c}, \mathrm{d}$ ) and examined Sox 2 expression. The results of both real-time PCR and immunoblotting showed that the depletion of Notch1 abolished the induction of Sox2 (Figure 4c,d), suggesting that Jagged1 and 2 activated Notch1 to induce Sox 2 expression.

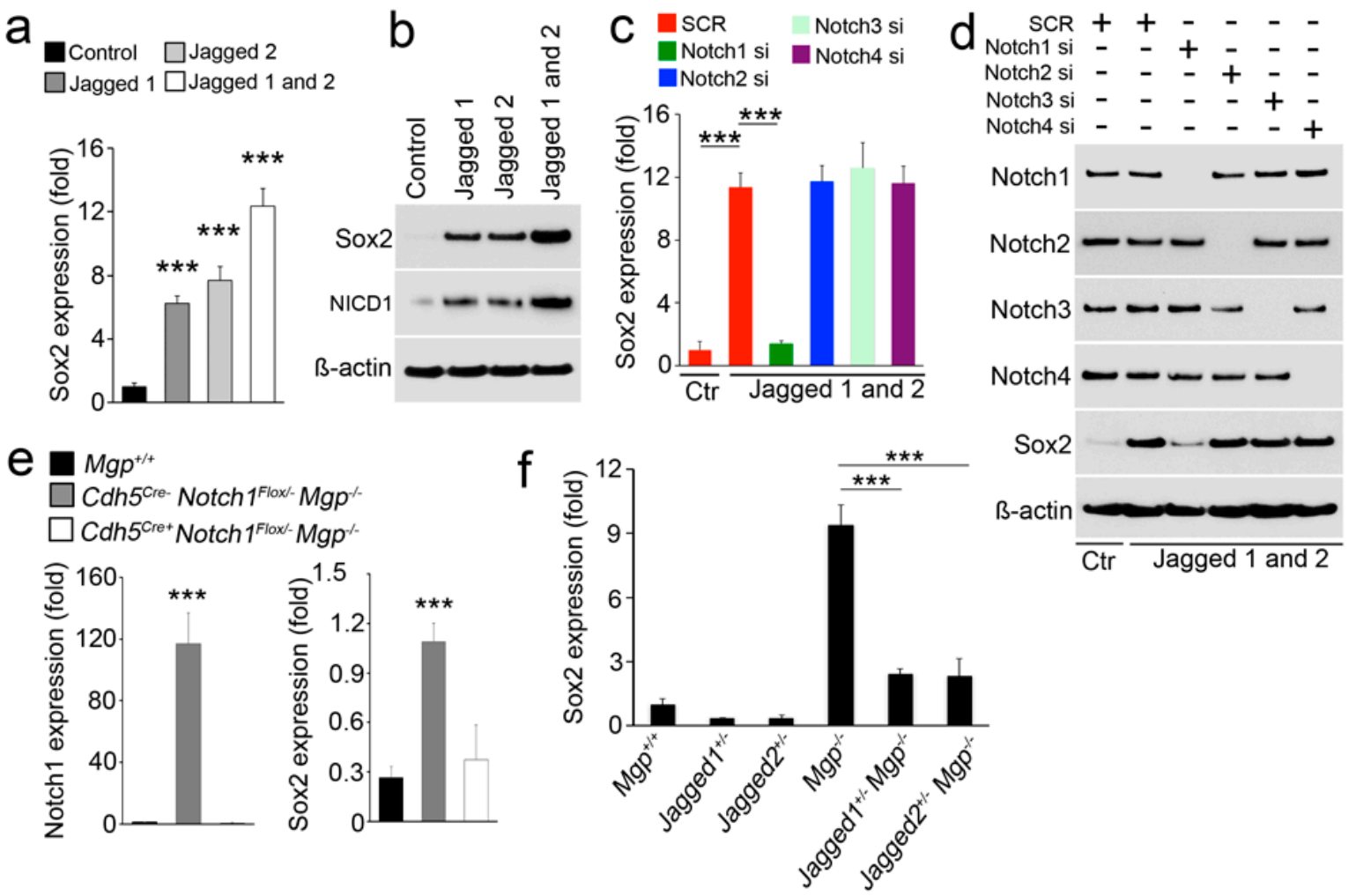

Figure 4. Excess Notch signaling induces Sox2 in cerebral ECs. (a,b) Sox2 expression in HBMECs treated with Jagged1, Jagged2, or their combination, as detected by real-time PCR (a) and immunoblotting (b). NICD1 was used as a control for the activation of Notch1 signaling. (c,d) Sox2 expression in HBMECs treated with Jagged1 and 2 after transfection with specific siRNAs (si) to Notch1, 2, 3, or 4 detected by real-time PCR (c) and immunoblotting (d). Ctr: control. (e) Expression of Notch1 and Sox2 in $\mathrm{Cdh}^{\mathrm{Cre}-} \mathrm{Notch}^{\mathrm{Flox} /-} \mathrm{Mgp}^{-/-}$and $\mathrm{Cdh} 5^{\mathrm{Cre}+} \mathrm{Notch}^{\mathrm{Flox} /-} \mathrm{Mgp}^{-/-}$cerebral ECs. Wild-type ECs $\left(\mathrm{Mgp}^{+/+}\right)$were used as a control $(n=6)$. (f) Expression of Sox2 in cerebral ECs isolated from wild-type, Jagged $1^{+/-}$, Jagged $2^{+/-}, \mathrm{Mgp}^{-/-}$, Jagged $1^{+/-} \mathrm{Mgp}^{-/-}$, and Jagged ${ }^{+/-} \mathrm{Mgp}^{-/-}$mice. ${ }^{* * *} p<0.001$.

To confirm our results in vivo, we limited Notch1 expression in $\mathrm{Mgp}^{-/-}$ECs by breeding VE-cadherin (Cdh5) promoter-driven Cre transgenic mice $\left(C d h 5^{\text {cre }}\right)$ with Notch $1^{\text {Flox/- }}$ mice. We isolated cerebral ECs from Cdh5 ${ }^{\text {cre }} \mathrm{Notch}^{\mathrm{Flox} /-} \mathrm{Mgp}^{-/-}$mice and assessed the expression of Notch1 and Sox2. The results showed that limiting Notch1 abolished the induction of Sox2 in $\mathrm{Mgp}^{-/-}$cerebral ECs (Figure 4e). We also examined Sox 2 expression in cerebral ECs of Jagged $1^{+/} \mathrm{Mgp}^{-/}$and Jagged $2^{+-} \mathrm{Mgp}^{-/}$mice with reduced Jagged1 and 2 [4]. The results showed that limiting Jagged1 and 2 abolished the induction of Sox 2 in $\mathrm{Mgp}^{-/-}$cerebral ECs (Figure 4f). Together, the results showed that excess BMP6 activated ALK3 to induce Notch1 and Jagged1 and 2, which in turn induced the expression of Sox2 in cerebral ECs. 


\subsection{Excess Notch Signaling Alters the Regulatory Complex to Activate Sox2 Expression}

To determine how excess Notch signaling induced Sox2, we examined the binding of the recombination signal binding protein for immunoglobulin kappa J (RBPJk) in the Sox 2 promoter. RBPJk was reported to be activated by Notch signaling and recruit other Notch-associated factors to regulate the transcription of Notch target genes [31]. There are five RBPJk-binding sites located in a $5 \mathrm{~kb}$ region upstream of the Sox 2 promoter (Figure 5a) [25]. By utilizing specific antibodies to RBPJk, we performed chromatin immunoprecipitation (ChIP) to enrich RBPJk-bound genomic DNA from $\mathrm{Mgp}^{+/+}$and $\mathrm{Mgp}^{-/-}$ cerebral ECs and examined the actual RBPJ $\kappa$ binding around the five binding sites. The results showed that DNA binding by RBPJ $\kappa$ strongly increased at the binding sites 1, 2, and 5 in $\mathrm{Mgp}^{-/-}$ECs (Figure 5b), confirming that increased Notch signaling altered the transcriptional regulation of the Sox 2 gene.

a

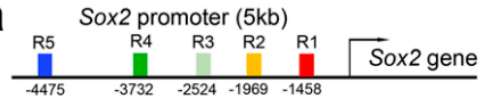

b

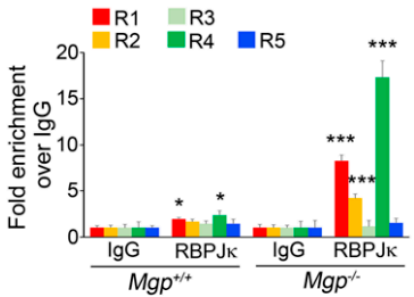

C

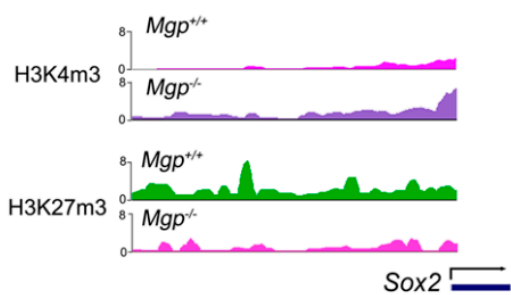

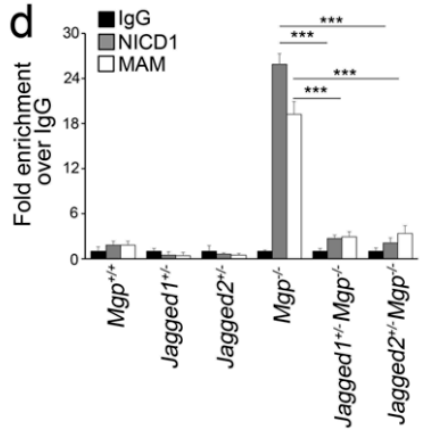

e

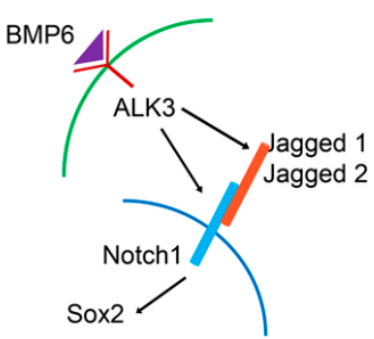

Figure 5. Notch signaling alters the regulatory complex in the Sox2 promoter to activate its expression in $\mathrm{Mgp}^{-/}$cerebral ECs. (a) Recombination signal binding protein for immunoglobulin kappa J (RBPJK) binding (R) sites in $+5 \mathrm{~kb}$ upstream of the regulatory region of the Sox 2 gene. (b) Chromatin immunoprecipitation (ChIP) assays demonstrating increased RBPJK binding in the Sox 2 regulatory region in $\mathrm{Mgp}^{-/-}$cerebral ECs. (c) ChIP-seq data demonstrating the occupation of the bivalent marks trimethylated histone $\mathrm{H} 3$ lysine 4 (H3K4me3) and trimethylated histone $\mathrm{H} 3$ lysine 27 (H3K27me3) around the Sox2 gene locus in $\mathrm{Mgp}^{+/+}$and $\mathrm{Mgp}^{-/-}$cerebral ECs. (d) ChIP assays demonstrating the increased binding of NICD1 and mastermind (MAM) around RBPJ $\kappa$ binding site 4 in the Sox2 regulatory region of $\mathrm{Mgp}^{-/-}$cerebral ECs and the abolished binding in Jagged $1^{+/-} \mathrm{Mgp}^{-/-}$and Jagged $2^{+/-} \mathrm{Mgp}^{-/-}$ cerebral ECs. ${ }^{*} p<0.05 ;{ }^{* * *} p<0.001$. (e) Schematic diagram.

To determine the status of chromatin around the Sox2 promoter in $\mathrm{Mgp}^{-/}$cerebral ECs, we performed a ChIP in parallel with massive sequencing (ChIP-seq). We examined the bivalent marks trimethylated histone $\mathrm{H} 3$ lysine 4 (H3K4me3) and trimethylated histone H3 lysine 27 (H3K27me3). $\mathrm{H} 3 \mathrm{~K} 4 \mathrm{me} 3$ is associated with active transcription, and H3K27me3 is associated with closed chromatin [32]. The results showed a significant increase of H3K4me3 and a decrease of H3K27me3 around the Sox 2 promoter in $\mathrm{Mgp}^{-/-}$ECs (Figure 5c), strongly indicating Sox 2 transcriptional activation.

Furthermore, we examined the abundance of NICD1 and Notch-associated protein mastermind (MAM) around RBPJ $\mathrm{k}$ binding site 4 in the Sox2 promoter in ECs from $\mathrm{Mgp}^{-/}$, Jagged1 ${ }^{+/-} \mathrm{Mgp}^{-/}$, and Jagged $2^{+-} \mathrm{Mgp}^{-/}$mice. Real-time PCR showed significant decreases in NICD1 and MAM binding in ECs from the Jagged $1^{+-} \mathrm{Mgp}^{-/}$and Jagged2 ${ }^{+/-} \mathrm{Mgp}^{-/}$mice (Figure 5d), further confirming that increased Notch signaling modified the complex of Notch-associated proteins in the Sox 2 promoter. 
Thus, we have identified BMP6 as an inducer of Notch components that alters the complex of Notch-associated proteins in the Sox 2 promoter and activates Sox2 expression in cerebral ECs (Figure 5e).

\section{Discussion}

BMP and Notch signaling interact in many developmental processes, such as heart development [33] and osteogenic differentiation [34]. The interplay between BMP and Notch signaling may alter the downstream effects of BMP [35-37] or change Notch activity on target genes [35-37], at least in part through the interaction between NICDs and SMADs [36,37]. Interactions between BMP and Notch signaling are also found in disease, such as cancer [38], pulmonary arterial hypertension [39], and valvular calcification [40]. Our previous studies showed that loss of the BMP inhibitor MGP enhanced BMP signaling and induced Notch signaling in cerebral ECs, resulting in cerebral AVMs [4]. However, the BMP ligands and receptors involved in this crosstalk were unclear. Here, we found that BMP6/ALK3 directly induced the Notch ligands Jagged1 and 2 and the Notch receptor Notch1 in brain ECs. The finding differs from the BMP9/ALK1 induction of all components previously described [4] and also shown in this study (Figure 2) and provides a new regulatory machinery in cerebral EC differentiation.

Interactions between Sox 2 and BMPs have been found in several cases during cell fate determination, including the differentiation of epithelial stem cells in molars and incisors [41], corneal endothelial cells [42], and gastric cells [43]. Moreover, loss of BMP inhibition, such as in MGP deficiency, induces Sox 2 and triggers ECs to undergo endothelial-mesenchymal transitions [18]. It is possible that Sox 2 and BMPs modulate mutual transitions of endothelium and mesenchyme to achieve cell differentiation, as well as the coordination between tissue-specific elements and vasculature.

Although the interaction between Sox 2 and Notch signaling in ECs constitutes a new field of investigation, previous studies have indicated the possibility of this connection. In fact, both Notch and Sox2 are involved in epithelial-mesenchymal transitions [16,44] and in the specification of sensory cell progenitors in the ear [45]. Notch regulates Sox 2 in neural stem cells [25] and cochlear development [46], and the levels of Sox 2 affect Notch signaling in tumorigenesis [47]. Here, our results provide a new link between Notch and Sox 2 in EC differentiation and vascular formation. We showed that Sox 2 is a direct target of Notch signaling in brain ECs and that the DNA binding of RBPJ $\kappa$ in the Sox 2 promoter is elevated with excess BMP activity. Since pSMAD1/5/8 are also increased in $M g p^{-/-}$-null ECs, the possibility remains that RBPJ $\kappa$ interacts with the SMADs to regulate Sox2 expression. Together, our findings enhance our understanding of cerebral EC differentiation on a transcriptional level as the basis of cerebral vascular disease.

Author Contributions: Y.Y. and K.I.B. supervised the experiments, analyzed the data, and wrote the manuscript. X.W., J.Y., L.W., D.Z., L.Z., E.X.R., and T.Y. performed experiments and data analysis.

Funding: Funding for this work was provided in part by NIH grants NS79353 (Y.Y.), HL139675 (Y.Y.), HL30568 (K.I.B.), and HL81397 (K.I.B.).

Conflicts of Interest: The authors have declared that no conflict of interest exists.

\section{References}

1. Govani, F.S.; Shovlin, C.L. Hereditary haemorrhagic telangiectasia: A clinical and scientific review. Eur. J. Hum. Genet. 2009, 17, 860-871. [CrossRef] [PubMed]

2. Urness, L.D.; Sorensen, L.K.; Li, D.Y. Arteriovenous malformations in mice lacking activin receptor-like kinase-1. Nat. Genet. 2000, 26, 328-331. [CrossRef] [PubMed]

3. Maddaluno, L.; Rudini, N.; Cuttano, R.; Bravi, L.; Giampietro, C.; Corada, M.; Ferrarini, L.; Orsenigo, F.; Papa, E.; Boulday, G.; et al. EndMT contributes to the onset and progression of cerebral cavernous malformations. Nature 2013, 498, 492-496. [CrossRef] [PubMed] 
4. Yao, Y.; Yao, J.; Radparvar, M.; Blazquez-Medela, A.M.; Guihard, P.J.; Jumabay, M.; Bostrom, K.I. Reducing Jagged 1 and 2 levels prevents cerebral arteriovenous malformations in matrix Gla protein deficiency. Proc. Natl. Acad. Sci. USA 2013, 110, 19071-19076. [CrossRef] [PubMed]

5. Yao, Y.; Jumabay, M.; Wang, A.; Bostrom, K.I. Matrix Gla protein deficiency causes arteriovenous malformations in mice. J. Clin. Investig. 2011, 121, 2993-3004. [CrossRef] [PubMed]

6. Benedito, R.; Trindade, A.; Hirashima, M.; Henrique, D.; da Costa, L.L.; Rossant, J.; Gill, P.S.; Duarte, A. Loss of Notch signalling induced by Dll4 causes arterial calibre reduction by increasing endothelial cell response to angiogenic stimuli. BMC Dev. Biol. 2008, 8, 117. [CrossRef] [PubMed]

7. Sainson, R.C.; Aoto, J.; Nakatsu, M.N.; Holderfield, M.; Conn, E.; Koller, E.; Hughes, C.C. Cell-autonomous notch signaling regulates endothelial cell branching and proliferation during vascular tubulogenesis. FASEB J. 2005, 19, 1027-1029. [CrossRef]

8. Krebs, L.T.; Shutter, J.R.; Tanigaki, K.; Honjo, T.; Stark, K.L.; Gridley, T. Haploinsufficient lethality and formation of arteriovenous malformations in Notch pathway mutants. Genes Dev. 2004, 18, 2469-2473. [CrossRef]

9. Lawson, N.D.; Scheer, N.; Pham, V.N.; Kim, C.H.; Chitnis, A.B.; Campos-Ortega, J.A.; Weinstein, B.M. Notch signaling is required for arterial-venous differentiation during embryonic vascular development. Development 2001, 128, 3675-3683.

10. Murphy, P.A.; Lam, M.T.; Wu, X.; Kim, T.N.; Vartanian, S.M.; Bollen, A.W.; Carlson, T.R.; Wang, R.A. Endothelial Notch4 signaling induces hallmarks of brain arteriovenous malformations in mice. Proc. Natl. Acad. Sci. USA 2008, 105, 10901-10906. [CrossRef]

11. Uyttendaele, H.; Ho, J.; Rossant, J.; Kitajewski, J. Vascular patterning defects associated with expression of activated Notch4 in embryonic endothelium. Proc. Natl. Acad. Sci. USA 2001, 98, 5643-5648. [CrossRef] [PubMed]

12. Yao, J.; Guihard, P.J.; Blazquez-Medela, A.M.; Guo, Y.; Liu, T.; Bostrom, K.I.; Yao, Y. Matrix Gla protein regulates differentiation of endothelial cells derived from mouse embryonic stem cells. Angiogenesis 2016, 19, 1-7. [CrossRef] [PubMed]

13. Wegner, M. From head to toes: The multiple facets of Sox proteins. Nucleic Acids Res. 1999, 27, 1409-1420. [CrossRef] [PubMed]

14. Sarkar, A.; Hochedlinger, K. The sox family of transcription factors: Versatile regulators of stem and progenitor cell fate. Cell Stem Cell 2013, 12, 15-30. [CrossRef] [PubMed]

15. Pispa, J.; Thesleff, I. Mechanisms of ectodermal organogenesis. Dev. Biol. 2003, 262, 195-205. [CrossRef]

16. Mandalos, N.; Rhinn, M.; Granchi, Z.; Karampelas, I.; Mitsiadis, T.; Economides, A.N.; Dolle, P.; Remboutsika, E. Sox2 acts as a rheostat of epithelial to mesenchymal transition during neural crest development. Front. Physiol. 2014, 5, 345. [CrossRef] [PubMed]

17. Luo, W.; Li, S.; Peng, B.; Ye, Y.; Deng, X.; Yao, K. Embryonic stem cells markers SOX2, OCT4 Nanog expression and their correlations with epithelial-mesenchymal transition in nasopharyngeal carcinoma. PLOS ONE 2013, $8, \mathrm{e} 56324$.

18. Yao, J.; Guihard, P.J.; Blazquez-Medela, A.M.; Guo, Y.; Moon, J.H.; Jumabay, M.; Bostrom, K.I.; Yao, Y. Serine Protease Activation Essential for Endothelial-Mesenchymal Transition in Vascular Calcification. Circ. Res. 2015, 117, 758-769. [CrossRef]

19. Yao, Y.; Jumabay, M.; Ly, A.; Radparvar, M.; Wang, A.H.; Abdmaulen, R.; Bostrom, K.I. Crossveinless 2 regulates bone morphogenetic protein 9 in human and mouse vascular endothelium. Blood 2012, 119, 5037-5047. [CrossRef]

20. He, L.; Vanlandewijck, M.; Mae, M.A.; Andrae, J.; Ando, K.; Del Gaudio, F.; Nahar, K.; Lebouvier, T.; Lavina, B.; Gouveia, L.; et al. Single-cell RNA sequencing of mouse brain and lung vascular and vessel-associated cell types. Sci. Data 2018, 5, 180160. [CrossRef]

21. Bostrom, K.; Zebboudj, A.F.; Yao, Y.; Lin, T.S.; Torres, A. Matrix GLA protein stimulates VEGF expression through increased transforming growth factor-beta1 activity in endothelial cells. J. Biol. Chem. 2004, 279, 52904-52913. [CrossRef] [PubMed]

22. Yao, Y.; Jumabay, M.; Ly, A.; Radparvar, M.; Cubberly, M.R.; Bostrom, K.I. A role for the endothelium in vascular calcification. Circ. Res. 2013, 113, 495-504. [CrossRef] [PubMed] 
23. Yao, J.; Guihard, P.J.; Wu, X.; Blazquez-Medela, A.M.; Spencer, M.J.; Jumabay, M.; Tontonoz, P.; Fogelman, A.M.; Bostrom, K.I.; Yao, Y. Vascular endothelium plays a key role in directing pulmonary epithelial cell differentiation. J. Cell Biol. 2017, 216, 3369-3385. [CrossRef] [PubMed]

24. Collas, P. The current state of chromatin immunoprecipitation. Mol. Biotechnol. 2010, 45, 87-100. [CrossRef] [PubMed]

25. Ehm, O.; Goritz, C.; Covic, M.; Schaffner, I.; Schwarz, T.J.; Karaca, E.; Kempkes, B.; Kremmer, E.; Pfrieger, F.W.; Espinosa, L.; et al. RBP Jkappa-dependent signaling is essential for long-term maintenance of neural stem cells in the adult hippocampus. J. Neurosci. Off. J. Soc. Neurosci. 2010, 30, 13794-13807. [CrossRef] [PubMed]

26. Shin, V.; Zebboudj, A.F.; Bostrom, K. Endothelial cells modulate osteogenesis in calcifying vascular cells. J. Vasc. Res. 2004, 41, 193-201. [CrossRef] [PubMed]

27. Yao, Y.; Shahbazian, A.; Bostrom, K.I. Proline and gamma-carboxylated glutamate residues in matrix Gla protein are critical for binding of bone morphogenetic protein-4. Circ. Res. 2008, 102, 1065-1074. [CrossRef] [PubMed]

28. Zebboudj, A.F.; Imura, M.; Bostrom, K. Matrix GLA protein, a regulatory protein for bone morphogenetic protein-2. J. Biol. Chem. 2002, 277, 4388-4394. [CrossRef]

29. Yao, Y.; Zebboudj, A.F.; Shao, E.; Perez, M.; Bostrom, K. Regulation of bone morphogenetic protein-4 by matrix GLA protein in vascular endothelial cells involves activin-like kinase receptor 1. J. Biol. Chem. 2006, 281, 33921-33930. [CrossRef]

30. Jumabay, M.; Zhumabai, J.; Mansurov, N.; Niklason, K.C.; Guihard, P.J.; Cubberly, M.R.; Fogelman, A.M.; Iruela-Arispe, L.; Yao, Y.; Saparov, A.; et al. Combined effects of bone morphogenetic protein 10 and crossveinless-2 on cardiomyocyte differentiation in mouse adipocyte-derived stem cells. J. Cell. Physiol. 2018, 233, 1812-1822. [CrossRef]

31. Hsieh, J.J.; Henkel, T.; Salmon, P.; Robey, E.; Peterson, M.G.; Hayward, S.D. Truncated mammalian Notch1 activates CBF1/RBPJk-repressed genes by a mechanism resembling that of Epstein-Barr virus EBNA2. Mol. Cell. Biol. 1996, 16, 952-959. [CrossRef] [PubMed]

32. Bernstein, B.E.; Mikkelsen, T.S.; Xie, X.; Kamal, M.; Huebert, D.J.; Cuff, J.; Fry, B.; Meissner, A.; Wernig, M.; Plath, K.; et al. A bivalent chromatin structure marks key developmental genes in embryonic stem cells. Cell 2006, 125, 315-326. [CrossRef] [PubMed]

33. Shen, Q.; Toulabi, L.B.; Shi, H.; Nicklow, E.E.; Liu, J. The forkhead transcription factor UNC-130/FOXD integrates both BMP and Notch signaling to regulate dorsoventral patterning of the $\mathrm{C}$. elegans postembryonic mesoderm. Dev. Biol. 2018, 433, 75-83. [CrossRef] [PubMed]

34. Cao, J.; Wei, Y.; Lian, J.; Yang, L.; Zhang, X.; Xie, J.; Liu, Q.; Luo, J.; He, B.; Tang, M. Notch signaling pathway promotes osteogenic differentiation of mesenchymal stem cells by enhancing BMP9/Smad signaling. Int. J. Mol. Med. 2017, 40, 378-388. [CrossRef] [PubMed]

35. Itoh, F.; Itoh, S.; Goumans, M.J.; Valdimarsdottir, G.; Iso, T.; Dotto, G.P.; Hamamori, Y.; Kedes, L.; Kato, M.; ten Dijke, P. Synergy and antagonism between Notch and BMP receptor signaling pathways in endothelial cells. EMBO J. 2004, 23, 541-551. [CrossRef] [PubMed]

36. Dahlqvist, C.; Blokzijl, A.; Chapman, G.; Falk, A.; Dannaeus, K.; Ibanez, C.F.; Lendahl, U. Functional Notch signaling is required for BMP4-induced inhibition of myogenic differentiation. Development 2003, 130, 6089-6099. [CrossRef]

37. Takizawa, T.; Ochiai, W.; Nakashima, K.; Taga, T. Enhanced gene activation by Notch and BMP signaling cross-talk. Nucleic Acids Res. 2003, 31, 5723-5731. [CrossRef]

38. Irshad, S.; Bansal, M.; Guarnieri, P.; Davis, H.; Al Haj Zen, A.; Baran, B.; Pinna, C.M.A.; Rahman, H.; Biswas, S.; Bardella, C.; et al. Bone morphogenetic protein and Notch signalling crosstalk in poor-prognosis, mesenchymal-subtype colorectal cancer. J. Pathol. 2017, 242, 178-192. [CrossRef]

39. Hurst, L.A.; Dunmore, B.J.; Long, L.; Crosby, A.; Al-Lamki, R.; Deighton, J.; Southwood, M.; Yang, X.; Nikolic, M.Z.; Herrera, B.; et al. TNFalpha drives pulmonary arterial hypertension by suppressing the BMP type-II receptor and altering NOTCH signalling. Nat. Commun. 2017, 8, 14079. [CrossRef]

40. Theodoris, C.V.; Li, M.; White, M.P.; Liu, L.; He, D.; Pollard, K.S.; Bruneau, B.G.; Srivastava, D. Human disease modeling reveals integrated transcriptional and epigenetic mechanisms of NOTCH1 haploinsufficiency. Cell 2015, 160, 1072-1086. [CrossRef] 
41. Li, J.; Feng, J.; Liu, Y.; Ho, T.V.; Grimes, W.; Ho, H.A.; Park, S.; Wang, S.; Chai, Y. BMP-SHH signaling network controls epithelial stem cell fate via regulation of its niche in the developing tooth. Dev. Cell 2015, 33, 125-135. [CrossRef] [PubMed]

42. Zhu, Y.T.; Li, F.; Han, B.; Tighe, S.; Zhang, S.; Chen, S.Y.; Liu, X.; Tseng, S.C. Activation of RhoA-ROCK-BMP signaling reprograms adult human corneal endothelial cells. J. Cell Biol. 2014, 206, 799-811. [CrossRef] [PubMed]

43. Camilo, V.; Barros, R.; Sousa, S.; Magalhaes, A.M.; Lopes, T.; Mario Santos, A.; Pereira, T.; Figueiredo, C.; David, L.; Almeida, R. Helicobacter pylori and the BMP pathway regulate CDX2 and SOX2 expression in gastric cells. Carcinogenesis 2012, 33, 1985-1992. [CrossRef] [PubMed]

44. Zakharova, L.; Nural-Guvener, H.; Gaballa, M.A. Cardiac explant-derived cells are regulated by Notch-modulated mesenchymal transition. PLoS ONE 2012, 7, e37800. [CrossRef] [PubMed]

45. Pan, W.; Jin, Y.; Chen, J.; Rottier, R.J.; Steel, K.P.; Kiernan, A.E. Ectopic expression of activated notch or SOX2 reveals similar and unique roles in the development of the sensory cell progenitors in the mammalian inner ear. J. Neurosci. Off. J. Soc. Neurosci. 2013, 33, 16146-16157. [CrossRef] [PubMed]

46. Liu, Z.; Owen, T.; Fang, J.; Srinivasan, R.S.; Zuo, J. In vivo Notch reactivation in differentiating cochlear hair cells induces Sox 2 and Prox1 expression but does not disrupt hair cell maturation. Dev. Dyn. Off. Publ. Am. Assoc. Anat. 2012, 241, 684-696.

47. Xu, X.; Huang, L.; Futtner, C.; Schwab, B.; Rampersad, R.R.; Lu, Y.; Sporn, T.A.; Hogan, B.L.M.; Onaitis, M.W. The cell of origin and subtype of K-Ras-induced lung tumors are modified by Notch and Sox2. Genes Dev. 2014, 28, 1929-1939. [CrossRef] [PubMed]

(C) 2019 by the authors. Licensee MDPI, Basel, Switzerland. This article is an open access article distributed under the terms and conditions of the Creative Commons Attribution (CC BY) license (http://creativecommons.org/licenses/by/4.0/). 